\title{
Correction to: Novel role of the Mu-opioid receptor in pancreatic cancer: potential link between opioid use and cancer progression
}

\author{
Muhammad R. Haque $^{1}$ (1) $\cdot$ Usman Barlass $^{1} \cdot$ Andrew Armstrong $^{1} \cdot$ Maliha Shaikh $^{1} \cdot$ Faraz Bishehsari $^{1}$ (D)
}

Published online: 25 February 2022

(c) The Author(s), under exclusive licence to Springer Science+Business Media, LLC, part of SpringerNature 2022

Correction to: Mol Cell Biochem (2022)

https://doi.org/10.1007/s11010-022-04377-5

In the original publication of the article, the copyright line was published incorrectly. The correct copyright line should be read as (C) The Author(s), under exclusive licence to Springer Science+Business Media, LLC, part of Springer Nature 2022.

The original article has been corrected.

Publisher's Note Springer Nature remains neutral with regard to jurisdictional claims in published maps and institutional affiliations.

The original article can be found online at https://doi.org/10.1007/ s11010-022-04377-5.

Faraz Bishehsari

Faraz_Bishehsari@rush.edu

1 Division of Digestive Diseases, Rush Center for Integrated

Microbiome \& Chronobiology Research, Medical Center,

Rush University, 1725 W Harrison St, Chicago, IL 60612,

USA 